\title{
Harbour seal Phoca vitulina movement patterns in the high-Arctic archipelago of Svalbard, Norway
}

\author{
Marie-Anne Blanchet ${ }^{1,2, *}$, Christian Lydersen ${ }^{1}$, Rolf A. Ims ${ }^{1,2}$, Andrew D. Lowther ${ }^{1}$, \\ Kit M. Kovacs ${ }^{1}$
}

\author{
${ }^{1}$ Norwegian Polar Institute, Framsentret, 9296 Tromsø, Norway \\ ${ }^{2}$ Department of Arctic and Marine Biology, UiT-Arctic University of Norway, 9037 Tromsø, Norway
}

\begin{abstract}
Harbour seals Phoca vitulina are mainly considered a temperate species, but the world's northernmost population resides year-round in the high-Arctic archipelago of Svalbard. In this study we document post-moulting at-sea movements of 30 individuals from this population using satellite relay data loggers deployed in the autumns of 2009 and 2010. All of the seals showed a strong preference for the west side of the archipelago, staying mainly in coastal areas $(<50 \mathrm{~km}$ over the continental shelf), but seldom entering the fjord systems. Distance swam per day, individual home range size, and trip duration increased throughout the winter to a peak that was reached when drifting sea ice in the region was at a maximum. No effect of age was observed, but sex differences were significant; males occupied larger areas than females. Habitat selection was quantified by modelling time spent in area (TSA) as a function of environmental parameters using Cox proportional hazard models $(\mathrm{CPH})$. The harbour seals avoided heavy ice concentrations $(>50 \%$ ) but did occupy areas with substantial amounts of drifting ice (5 to $25 \%$ ). Shallow water $(<100 \mathrm{~m})$ and steep bathymetric slopes were preferred to deep water or flat-bottom areas. Harbour seal distribution in Svalbard is largely restricted to coastal areas that are heavily influenced by Atlantic water brought northward in the West Spitsbergen Current; both the temperature and influx of this water type are predicted to increase in the future. It is thus likely that environmental conditions in Svalbard in the future will become more favourable for harbour seals.
\end{abstract}

KEY WORDS: Climate change $\cdot$ Sea ice $\cdot$ Habitat use $\cdot$ Time spent in area $\cdot$ Cox proportional hazard models $\cdot$ Satellite telemetry

\section{INTRODUCTION}

Harbour seals Phoca vitulina have one of the broadest distributions among the pinnipeds, ranging from temperate areas as far south as southern California and France to Arctic waters of the North Pacific and the North Atlantic (Bigg 1969, Thompson et al. 1989, Bjørge et al. 1995). This species was listed as 'Least Concern' by the IUCN Red List in 2008; at that time the global population was estimated to be 350000 to 500000 individuals. However, there have been major declines documented for some harbour seal populations in the last $20 \mathrm{yr}$ (Thompson \& Härkönen 2008), with currently ongoing declines in

*Corresponding author: marie-anne.blanchet@npolar.no some regions (Womble et al. 2010, Hanson et al. 2013, Matthiopoulos et al. 2014). Southern harbour seal populations are generally well-studied, protected from exploitation for the most part, and are stable or increasing (e.g. Chavez-Rosales \& Gardner 1999, Jeffries et al. 2003, Hassani et al. 2010, Olsen et al. 2010, Reijnders et al. 2010). However, the situation is quite different for northern populations, where up-to-date regional harbour seal abundance information is often lacking (despite local harvesting activities), and some populations have shown marked declines in both the North Atlantic (Lucas \& Stobo 2000, Hanson et al. 2013, Matthiopoulos et al. 2014) and the North Pacific (e.g. Frost et al. 1999, Small et

(C) The authors 2014. Open Access under Creative Commons by Attribution Licence. Use, distribution and reproduction are unrestricted. Authors and original publication must be credited. 
al. 2008, Womble et al. 2010). The reasons for the observed declines are not clear in all cases, but several hypotheses have been proposed that suggest climate change-related linkages such as shifts in prey distribution, increased predation pressure, vulnerability to pathogens or competitive stress (Trites et al. 2007, Matthiopoulos et al. 2014). The declines in harbour seal numbers in the Aleutian Islands and the Gulf of Alaska over the last 30 yr have been linked to a large-scale oceanographic regime shift that has likely been induced by climate change (Small et al. 2008, Womble et al. 2010). Sharkinflicted mortality seems to be a predominant factor for seal decline in Nova Scotia, where a large proportion of pups and adult females are killed by one or more shark species (Lucas \& Stobo 2000, Lucas \& Natanson 2010). The substantial decline in the number of harbour seals in the United Kingdom is partly attributable to 2 recent phocine distemper virus epidemics and some colonies have not recovered, particularly in Scotland where severe declines have been documented (Thompson et al. 2005, Lonergan et al. 2007, 2010, 2013, Hanson et al. 2013). Available information from Iceland, Greenland and mainland Norway suggest that harbour seal populations are severely depleted compared to former times, which has been driven in part by overharvesting, but other environmental pressures are likely also contributing to the downward trends (Hauksson 1992, Nilssen et al. 2010, Rosing-Asvid 2010).

The harbour seals in Svalbard constitute the world's northernmost population of this species. In many aspects this population is unique among harbour seals because it experiences a combination of extreme light, sea ice and temperature regimes, exhibits marked sexual dimorphism and individuals are shorter and heavier compared to conspecifics in other populations (Lydersen \& Kovacs 2010). No other population in the world encounters such a combination of extreme environmental conditions and only a handful of populations in Canada (Hudson Bay, Bajzak et al. 2013; St Lawrence River Estuary, Lesage et al. 2004) and Greenland (Rosing-Asvid 2010) encounter heavy seasonal sea-ice cover. The core of the harbour seal distribution within the Svalbard Archipelago is off the west coast of Prins Karl Forland. This area contains the only known pupping sites in Svalbard (Lydersen \& Kovacs 2010) but observations of hauled-out harbour seals are increasingly reported from other areas within the Svalbard Archipelago. This small, isolated population of ca. 2000 animals (Merkel et al. 2013) has low genetic diversity (Andersen et al. 2011); it is Red-listed in
Norway and hence protected from harvesting. The haul-out behaviour of this population has been studied intensively (Reder et al. 2003), and concomittantly with the current stud (see Hamilton et al. 2014), but the at-sea behaviour of adult harbor seals remains largely undocumented. A few animals in this population were tracked through the fall and early winter period via satellite tag deployments in the early 1990s (Gjertz et al. 2001) and 3 time-depth recorders (TDRs) were deployed for some weeks in the autumn of 1994 (Krafft et al. 2002). However, upto-date distributional information about areas occupied by this population in a broader seasonal perspective is not available.

The marked declines in Nordic harbour seal populations are likely to be at least partly the result of wide-scale ecosystems changes that are influencing predation levels on, or prey distribution of, harbour seals. However, currently there is insufficient information on the distribution and general ecology of harbour seals in Svalbard to evaluate the various influences of climatic change on this population. Thus, the objectives of this study were to examine present-day movement patterns and at-sea habitat preferences of harbour seals on Svalbard. This will provide a baseline for future studies exploring possible consequences of further climate change on this northernmost harbour seal population.

\section{MATERIALS AND METHODS}

\section{Tagging}

Thirty harbour seals were captured on the west coast of Prins Karl Forland (PKF; $78^{\circ} 20$ N, $11^{\circ} 30$ E) near a small group of islands (Forlandøyane), in the high-Arctic archipelago of Svalbard (see Fig. 1) in 2009 and 2010 ( $\mathrm{N}=15$ each year). The animals were captured immediately following their annual moult, between 23 August and 13 September using tangle nets set from shore near haul-out sites (see Lydersen \& Kovacs 2005 for details). None of the captured adult females was still caring for a pup as the peak of the pupping period occurs during the second half of June (Gjertz \& Børset 1992) and pups are weaned in July. All animals were weighed (Salter spring scales $\pm 0.5 \mathrm{~kg}$ ) and sex was determined. After being secured in individual holding nets the seals were immobilized with an intramuscular injection of Telazol (1 $\mathrm{mg} \mathrm{kg} \mathrm{kg}^{-1}$ for juveniles and adult females and $0.75 \mathrm{mg} \mathrm{kg}^{-1}$ for adult males) before a lower incisor was extracted for age determination and standard 
length and girth were measured to the nearest $\mathrm{cm}$ (Reder et al. 2003). Seals aged 1 or 2 yr were classified as juveniles while seals aged 6 yr or more were classified as mature. Seals aged 3, 4, or 5 yr were attributed a maturity status based on a combination of their length, girth and mass measurements following Lydersen \& Kovacs (2005).

All animals were equipped with conductivitytemperature-depth satellite relay data loggers (CTDSRDLs) (Sea Mammal Research Unit, University of St Andrews), glued onto the fur mid-dorsally in the neck area using quick-setting epoxy. Data collected by the CTD-SRDLs were transmitted via the Argos satellite system (System Argos). The instruments collected and relayed information on the animals' location, haul-out and dive behaviour, as well as providing CTD up-casts on selected dives (see Boehme et al. 2009 for details on the performance, sampling and transmission protocols of the tags). Only location data are the subject of this study. The CTD-SRDLs weighed $545 \mathrm{~g}$ in air, measured $10.5 \times 7 \times 4 \mathrm{~cm}$ and were programmed to send data whenever possible with no duty cycling. All of the seals were also tagged with uniquely numbered plastic tags (Dalton rototags) placed through the webbing of each hind flipper for permanent individual identification.

\section{Environmental data extraction}

All data processing and analyses were done using the $\mathrm{R}$ statistical framework ( $\mathrm{R}$ Development Core Team 2012). Sea ice classifications were based on daily polygon ice maps from the Norwegian Meteorological Institute; these are produced using a weather-independent SAR radar with a spatial resolution of $50 \mathrm{~m}$, using manual classification of areas into the following concentration categories (http://polarview.met.no/) - (1) open water: 0/10-1/10; (2) very open drift ice: $1 / 10-4 / 10$; (3) open drift ice: $4 / 10-7 / 10$; (4) close drift ice: $7 / 10-9 / 10$; (5) very close drift ice: 9/10-10/10 and; (6) fast ice. Average monthly ice concentrations and sea ice extent were also calculated using the daily ice maps (R package 'Raster'; Hijmans 2014); extent was calculated as the sea surface area covered by an ice concentration of at least $25 \%$ (corresponding to the category very open drift ice).

Bathymetry was extracted from a $0.5 \times 0.5 \mathrm{~km}$ resolution data set from the International Bathymetric Chart of the Arctic Ocean (IBCAO v.3.0, 2012, www.ibcao.org; Jakobsson et al. 2012) and slope was calculated based on the bathymetry map using val- ues from 8 neighbouring spatial grid cells. Distance to the coast and from the tagging location were calculated in ArcInfo 10 (ESRI), using Norwegian Polar Institute coastline maps (scale 1:250 000) that were produced using aerial photographs of coastlines taken in the period from 1993 to 1998 (with regular updates on the locations of glacier fronts).

\section{Data processing}

Satellite-derived location estimates obtained from Service Argos are assigned a location class (LC) based on the number of uplinks received by a passing satellite. LC 3, 2, and 1 have the highest quality with an accuracy ranging from $<150 \mathrm{~m}$ for LC 3 to $1000 \mathrm{~m}$ for LC 1, while LC 0 has unbounded accuracy $(>1000 \mathrm{~m})$ and no accuracy information is provided for LC A and B (www.cls.fr/manual). Locations reported for each seal were first filtered using a speed distance and angle filter (SDA filter; Freitas et al. 2008a) that removes all LC $Z$ values and points requiring unrealistic swimming speeds $\left(>2 \mathrm{~m} \mathrm{~s}^{-1}\right)$ or unlikely turning angles (all spikes with angles smaller than 15 or 25 degrees were removed if their lengths were greater than 2.5 or $5 \mathrm{~km}$, respectively) using the R package 'argosfilter' (Freitas 2013). The remaining location estimates were then processed further using a Kalman filter under a state-space framework using the $\mathrm{R}$ package 'crawl' (Johnson 2013) that incorporates a covariate for Argos location error (when available) for each of the 6 LCs $(3,2$, $1,0, A, B)$. In addition a covariate encompassing the time the animal was hauled out was included allowing the movement along a track line to completely stop during a haul-out event. Processing the raw location estimates in this manner resulted in a model of the most likely track, from which point location estimates could be made for any specific time. Hourly locations were estimated by interpolation using this model; these positions were used for further calculations.

\section{Movement parameters}

Movement parameters were calculated for each seal; total distance swum $(\mathrm{km})$, monthly average maximum distance $(\mathrm{km})$ from the tagging location and average trip duration (h). A trip was defined as the time between 2 sequential haul-outs, while a foraging trip was defined as an excursion of at least $3 \mathrm{~h}$ duration that took place between 2 successive 
haul-out events; the $3 \mathrm{~h}$ lower limit was set in order to avoid over-emphasizing brief excursions into the water that harbour seals often do close to haul-out locations (Thompson et al. 1998a, Krafft et al. 2002, Blundell et al. 2011). The influence of calendar month, year and sex was tested on each of the movement parameters using linear mixed effects models (LME) ('nlme' package; Pinheiro et al. 2014). Interactions between sex and year, and month and year, were considered whereas interactions between sex and calendar month were not, due the low number of females still transmitting data from February onward in both years (see Table 1). Possible seasonal trends in trip duration were explored using a generalized additive mixed-effects model (GAMM). Trip departure date was entered as a smoothed term based on the number of days since 01 September with a separate smoothed term fitted for each year. Individual animal ID was included as a random effect to deal with pseudoreplication affiliated with multiple points from individual animals.

\section{Home range calculations}

Home ranges (HR) were calculated for each animal for each month, for individuals with at least $25 \mathrm{~d}$ of tracking data within a given month, by taking $95 \%$ of the estimated utilization distribution (UD) (Worton 1989). The UD function was estimated using a kernel method based on Brownian bridge movement (Horne et al. 2007) in the package 'adehabitatHR' (Calenge 2011). This method takes into account the path travelled by the animal between 2 successive locations, whereas classical kernel methods only consider point patterns. Therefore, it avoids identifying areas between habitat patches that were actually not used by the animal (Calenge 2011). The smoothing parameter of the kernel depends on the accuracy and the average number of locations per day after filtering by the state-space model used to calculate the HR. The post-filtering location accuracy was taken from Patterson et al. (2010) based on the mean number of locations per day. HR areas were compared across years, months, ages and sexes and environmental parameters such as sea ice extent using LME. Possible interactions between year and month were tested, but potential influences of sex with sea ice extent and month could not be explored due to the low number of instruments that were still transmitting data from females late in each deployment period. All models were fitted using maximum likelihood methods to ensure they were comparable. Post- hoc multiple comparison tests were performed using Tukey's pairwise comparisons ('multicomp' package; Hothorn et al. 2014) to test for differences between each month. HR sizes were log-transformed to achieve normality and homogeneity of variances. Animal ID was used as a random effect and 95\% confidence intervals were calculated using 500 bootstrap resamples. A first order, moving average, autocorrelation term was chosen to account for temporal autocorrelation between successive months. Model validation was performed by visually inspecting the residuals and model selection was done using Bayesian information criterion (BIC) that penalizes overfitting (Burnham \& Anderson 2002).

\section{Habitat use}

To quantify space use relative to environmental conditions experienced while at-sea during foraging trips, the time spent at sea (h) was calculated based on a spatial grid with $2.5 \times 2.5 \mathrm{~km}$ cells (package 'trip'; Sumner \& Luque 2013). Each cell was assigned the geographical location of its centre to facilitate extracting environmental parameters such as bathymetry and slope of the sea floor. Furthermore, a time stamp corresponding to the mean point of the foraging trip was identified in order to be able to associate each value for time spent in a grid cell with data that best described local, dynamic environmental variables such as sea ice. Time spent in area (TSA) per trip was then modelled using mixed-effect Cox proportional-hazards models (CPH) (Cox 1972) in order to see how seal movements were influenced by environmental and intrinsic variables as described in Freitas et al. (2008b). The models were in the form: $h(t)=\exp \left(\beta_{1} X_{1}+\beta_{2} X_{2}+\ldots \ldots \beta_{\mathrm{p}} X_{\mathrm{p}}+b\right) h_{0}(t)$, where $h(t)$ is the hazard function representing the risk of an individual leaving an area (defined by a $2.5 \times 2.5 \mathrm{~km}$ cell) at time $t_{i} X$ represents an environmental variable (explanatory variable) and; $\beta_{x}$ denotes the regression coefficient describing the contribution of the variable $X$. The $b$ term represents the per-subject random effect and $h_{0}(t)$ is the baseline hazard function at time $t$, or in other words the risk of leaving an area when all explanatory variables are equal to zero. In this context, the word 'risk' does not imply a negative consequence of the action of leaving an area, but simply depicts the probability of leaving an area given a certain value of the covariates. The hazard ratio $\exp (\beta)$ represents the ratio between the hazard of leaving when the value of the $X$ explanatory variable is increased by 1 unit if $X$ is continuous or, 
in other words, the relative probability of leaving an area when $X$ is increased by 1 unit. If $X$ is categorical, the hazard ratio (or relative probability) represents the ratio between the hazard of leaving when $X$ assumes a given level and the hazard of leaving when $X$ is equal to a defined reference level. A hazard ratio higher than 1 indicates an increased risk of leaving (or increased probability) and a hazard ratio lower than 1 indicates a lower risk of leaving. Hazard ratios therefore provide a quantitative way to assess how each parameter influences habitat selection: in other words, it is assumed that if an animal remains in an area for an extended period of time, it is likely a favourable habitat. Individual seal ID was included as a frailty term in the model to account for individual variability and to be able to select between a set of candidate models while keeping the individual effect within the model. The predictive map was calculated without the frailty term because the method to predict values from a proportional hazard mixed effect model is not yet implemented in R. However, parameter estimates of models with and without the frailty term were very similar suggesting that the predictions are unbiased. All possible additive combinations of environmental (bathymetry, slope, sea ice concentration, distance-to-coast), time (mo) and individual parameters (sex, age) were tested and optimal models were selected using BIC. In addition the interactions distance to coast $\times$ month and distanceto-coast $\times$ sea ice concentration were included to see if TSA at different distances to the coast depended on the time of year or on ice concentration, respectively. Similar to the LME analyses described earlier, interactions with sex were not considered here due to the low number of CTD-SRDLs still transmitting data from female seals during the latter stages of the 2 deployment periods. The assumption of proportional hazard ratios (i.e. the hazard ratio of 2 observations being independent of time) was verified for the final model by checking the scaled Schoefeld residuals visually and by testing if their slope was zero (Collett 2003). All models were fitted in R using 'survival' and 'coxme' (Therneau 2012).

\section{RESULTS}

The CTD-SRDLs deployed on adult and juvenile harbour seals $(\mathrm{N}=30)$ in this study provided data for periods ranging between 54 and $298 \mathrm{~d}$, with an average individual data record of $200 \pm 79$ d (Table 1). Twelve animals had records that extended into the month of June in the year following tag deployment; but all tags ceased to function before July. Year of tag deployment (ANOVA $F_{1,58}=2.14, \mathrm{p}=0.15$ ) and seal age class (ANOVA $F_{1,58}=0.92, \mathrm{p}=0.40$ ) had no effect on the duration of the tracking records; but males had longer data records than females in both years (ANOVA $F_{1,58}=6.62, \mathrm{p}<0.01$ ). There was no difference in body length within age groups $\left(\mathrm{ANOVA}_{\mathrm{ad}}\right.$ $F_{1,12}=1.80, \mathrm{p}=0.30 ;$ ANOVA $_{\text {juv }} F_{1,14}=1.12, \mathrm{p}=0.30$ ) or sexes between the 2 different study years $\left(\mathrm{ANOVA}_{\mathrm{M}}\right.$ $\left.F_{1,13}=0.06, \mathrm{p}=0.81 ; \mathrm{ANOVA}_{\mathrm{F}} F_{1,13}=0.22, \mathrm{p}=0.65\right)$.

\section{At-sea movements}

Seal locations were concentrated in an area that was on average within $82 \mathrm{~km}( \pm 58 \mathrm{~km})$ north or south of the tagging location. All of the animals stayed close to the coast, within $50 \mathrm{~km}$ west of PKF and none of the instrumented animals travelled to the east coast of Spitsbergen (Fig. 1). Similarly, most of the animals did not go south of $77.5^{\circ} \mathrm{N}$ or north of $80^{\circ} \mathrm{N}$, except in 2010 when 4 males spent some time outside these boundaries. The total distance swum per month ranged between 70 and $1362 \mathrm{~km}$, with clear differences being displayed between sexes and months. The top 3 LMEs with a combined $\mathrm{AIC}_{\mathrm{C}}$ weight of 0.7 did not include the interactions between year and month and between sex and year. The most parsimonious model included month and sex $\left(\mathrm{AIC}_{\mathrm{C}}=160.9\right)$. Males travelled more than females (mean dist $_{\mathrm{M}}=$ $648 \pm 295 \mathrm{~km}$; dist $_{\mathrm{F}}=383 \pm 186 \mathrm{~km}$ ) and all animals covered more distance during the winter and spring months (December through May) compared to the fall (September through November) (mean dist $_{\text {Dec-May }}=705 \pm 291 \mathrm{~km}$; mean dist Sep-Nov $=368 \pm$ $143 \mathrm{~km}$ ). The most parsimonious LME model explaining the monthly maximum distance from the tagging location included year and month $\left(\mathrm{AIC}_{\mathrm{C}}=278 ; \mathrm{AIC}_{\mathrm{C}}\right.$ weight $=0.371)$. Animals travelled further away from the tagging location in 2009 compared to 2010 (mean dist $_{2009}=53 \pm 38 \mathrm{~km}$; mean dist $2010=114 \pm 59 \mathrm{~km}$ ) and all animals were further away from PKF during the winter and spring months compared to the fall (mean dist $_{\text {Sep-Nov }}=69 \pm 55 \mathrm{~km}$; mean dist ${ }_{\text {Dec-May }}=95 \pm 58 \mathrm{~km}$ ). Monthly tracks were longer and the animals were progressively further away from the tagging location as winter set in (Fig. 2). Four males travelled more than $200 \mathrm{~km}$ from the tagging location (Table 1). The best GAMM model describing the variation in trip duration included date as a smooth curve, fitted separately for each tagging year. Sex and age were not included in the best model (Table 2). Trip duration varied with the season in both years, though markedly 
Table 1. Phoca vitulina. Summary of the locations data for 30 harbour seals equipped with CTD satellite relay data loggers (CTD-SRDLs) in Svalbard in 2009 and 2010. Ad: adult; Juv: juvenile; M: male; F: female; dist: distance; loc(s): location(s); tag: tagging. Deployment date is shown as $\mathrm{dd} / \mathrm{mm} /$ yyyy

\begin{tabular}{|c|c|c|c|c|c|c|c|c|c|c|c|}
\hline Seal ID & Sex & $\begin{array}{l}\text { Mass } \\
(\mathrm{kg})\end{array}$ & $\begin{array}{l}\text { Girth } \\
(\mathrm{cm})\end{array}$ & $\begin{array}{l}\text { Length } \\
\text { (cm) }\end{array}$ & $\begin{array}{l}\text { Age } \\
\text { class }\end{array}$ & $\begin{array}{l}\text { Age } \\
\text { (yr) }\end{array}$ & $\begin{array}{l}\text { Deployment } \\
\text { date }\end{array}$ & $\begin{array}{l}\text { Tagging } \\
\text { duration } \\
\text { (d) }\end{array}$ & $\begin{array}{l}\text { Mean no. } \\
\text { of filtered } \\
\text { locs } \mathrm{d}^{-1}\end{array}$ & $\begin{array}{l}\text { Total dist } \\
\text { travelled } \\
(\mathrm{km})\end{array}$ & $\begin{array}{l}\text { Max. dist } \\
\text { from tag } \\
\text { loc }(\mathrm{km})\end{array}$ \\
\hline ct52-F41-09 & F & 41.0 & 90 & 104 & Juv & 2 & 02/09/2009 & 278 & 4.8 & 2866.7 & 76.5 \\
\hline ct52-F44-09 & $\mathrm{F}$ & 44.0 & 89 & 116 & Juv & 2 & 02/09/2009 & 147 & 7.7 & 1491.2 & 70.1 \\
\hline ct52-F47-09 & $\mathrm{F}$ & 47.0 & 92 & 118 & Juv & 2 & 02/09/2009 & 129 & 11.1 & 1627.9 & 67.0 \\
\hline ct52-F48-09 & $\mathrm{F}$ & 48.0 & 93 & 120 & Juv & 3 & 01/09/2009 & 101 & 10.5 & 1052.6 & 63.9 \\
\hline ct52-F60-09 & $\mathrm{F}$ & 60.0 & 98 & 126 & $\mathrm{Ad}$ & 4 & 02/09/2009 & 201 & 8.4 & 3111.2 & 185.3 \\
\hline ct52-F66-09 & $\mathrm{F}$ & 66.0 & 100 & 133 & $\mathrm{Ad}$ & 5 & 02/09/2009 & 116 & 9.1 & 1092.5 & 22.0 \\
\hline ct52-F74-09 & $\mathrm{F}$ & 74.0 & 108 & 139 & $\mathrm{Ad}$ & 11 & 01/09/2009 & 160 & 4.6 & 1096.8 & 70.8 \\
\hline ct52-F76-09 & $\mathrm{F}$ & 76.0 & 107 & 139 & Ad & 9 & 04/09/2009 & 280 & 11.0 & 4082.6 & 41.8 \\
\hline ct52-M43-09 & M & 43.0 & 86 & 113 & Juv & 2 & 04/09/2009 & 177 & 9.3 & 3239.5 & 150.7 \\
\hline ct52-M51-09 & M & 51.0 & 96 & 120 & Juv & 2 & 04/09/2009 & 279 & 12.8 & 6402.8 & 64.5 \\
\hline ct52-M52-09 & M & 52.0 & 98 & 122 & Juv & 2 & 05/09/2009 & 277 & 12.5 & 6040.3 & 81.5 \\
\hline ct52-M56-09 & M & 56.0 & 101 & 128 & Ad & 4 & 04/09/2009 & 284 & 11.0 & 5653.4 & 49.7 \\
\hline ct52-M64-09 & M & 64.0 & 94 & 130 & $\mathrm{Ad}$ & 3 & 05/09/2009 & 256 & 10.8 & 4919.5 & 71.6 \\
\hline ct52-M65-09 & M & 65.0 & 109 & 128 & $\mathrm{Ad}$ & 3 & 13/09/2009 & 268 & 8.0 & 4396.7 & 72.4 \\
\hline ct52-M77-09 & M & 77.0 & 111 & 142 & Ad & 5 & 10/09/2009 & 107 & 6.8 & 1211.8 & 73.2 \\
\hline ct69-F42-10 & $\mathrm{F}$ & 42.0 & 88 & 109 & Juv & 2 & $26 / 08 / 2010$ & 151 & 3.5 & 563.9 & 71.1 \\
\hline ct69-F44-10 & $\mathrm{F}$ & 44.0 & 88 & 116 & Juv & 3 & $28 / 08 / 2010$ & 144 & 6.2 & 1791.8 & 76.8 \\
\hline ct69-F50-10 & $\mathrm{F}$ & 50.0 & 87 & 127 & Juv & 3 & $23 / 08 / 2010$ & 54 & 10.6 & 649.6 & 16.2 \\
\hline ct69-F53-10 & $\mathrm{F}$ & 53.0 & 92 & 120 & $\mathrm{Ad}$ & 4 & 03/09/2010 & 157 & 6.2 & 2861.8 & 180.2 \\
\hline ct69-F58a-10 & $\mathrm{F}$ & 58.0 & 95 & 124 & Ad & 5 & $25 / 08 / 2010$ & 86 & 5.8 & 1492.3 & 61.6 \\
\hline ct69-F58b-10 & $\mathrm{F}$ & 58.0 & 94 & 132 & Ad & 5 & $28 / 08 / 2010$ & 297 & 9.5 & 5675.9 & 86.0 \\
\hline ct69-F59-10 & $\mathrm{F}$ & 59.0 & 93 & 125 & Juv & 3 & 03/09/2010 & 103 & 2.3 & 993.2 & 85.0 \\
\hline ct69-M41-10 & M & 41.0 & 89 & 105 & Juv & 1 & $25 / 08 / 2010$ & 284 & 9.0 & 6954.3 & 180.2 \\
\hline ct69-M45-10 & M & 45.0 & 86 & 122 & Juv & 2 & $31 / 08 / 2010$ & 151 & 3.5 & 1585.9 & 103.7 \\
\hline ct69-M48-10 & M & 48.0 & 86 & 128 & Juv & 3 & $24 / 08 / 2010$ & 288 & 6.4 & 6157.5 & 222.7 \\
\hline ct69-M53a-10 & M & 53.0 & 97 & 126 & Juv & 3 & $30 / 08 / 2010$ & 293 & 7.3 & 7401.2 & 178.6 \\
\hline ct69-M53b-10 & M & 53.0 & 93 & 123 & Juv & 2 & 03/09/2010 & 176 & 9.3 & 3369.7 & 74.9 \\
\hline ct69-M57-10 & M & 57.0 & 96 & 132 & Ad & 5 & $24 / 08 / 2010$ & 299 & 8.6 & 6953.3 & 228.1 \\
\hline ct69-M64-10 & M & 64.0 & 104 & 127 & Ad & 4 & 26/08/2010 & 289 & 11.0 & 8194.3 & 207.8 \\
\hline ct69-M65-10 & M & 65.0 & 95 & 137 & Ad & 5 & $24 / 08 / 2010$ & 235 & 11.1 & 6279.1 & 209.0 \\
\hline
\end{tabular}
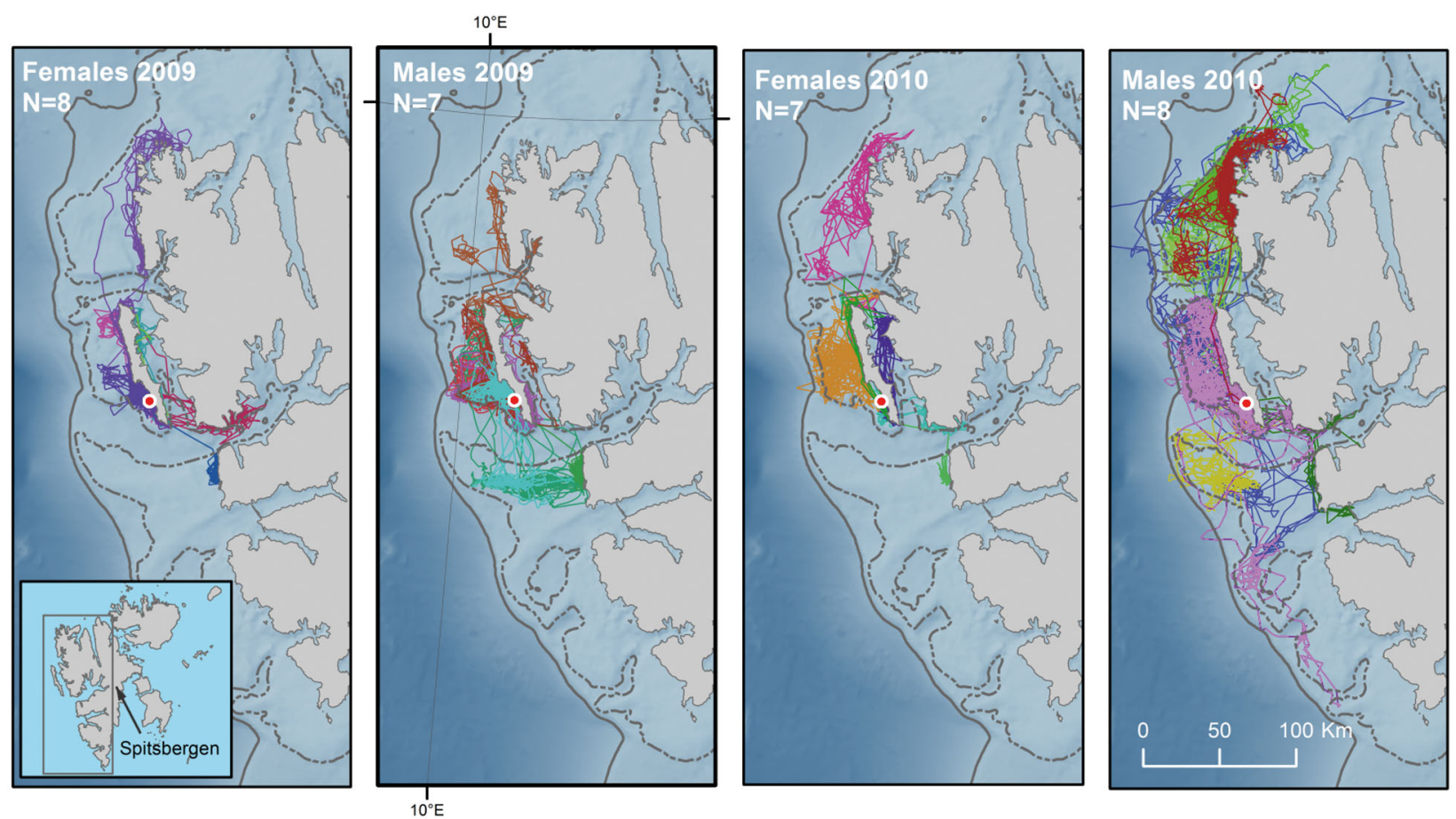

Fig. 1. Phoca vitulina. Filtered tracks of the 30 adult or juvenile harbour seals equipped with CTD satellite relay data loggers in Svalbard, Norway during 2009 and 2010, overlaid on bathymetry (darker shades indicate deeper water). The $500 \mathrm{~m}$ (solid grey line) and $200 \mathrm{~m}$ (dashed grey line) isobaths are shown. The red dot represents the tagging location on Forlandøyane. The inset shows the Svalbard Archipelago and the island of Spitsbergen 

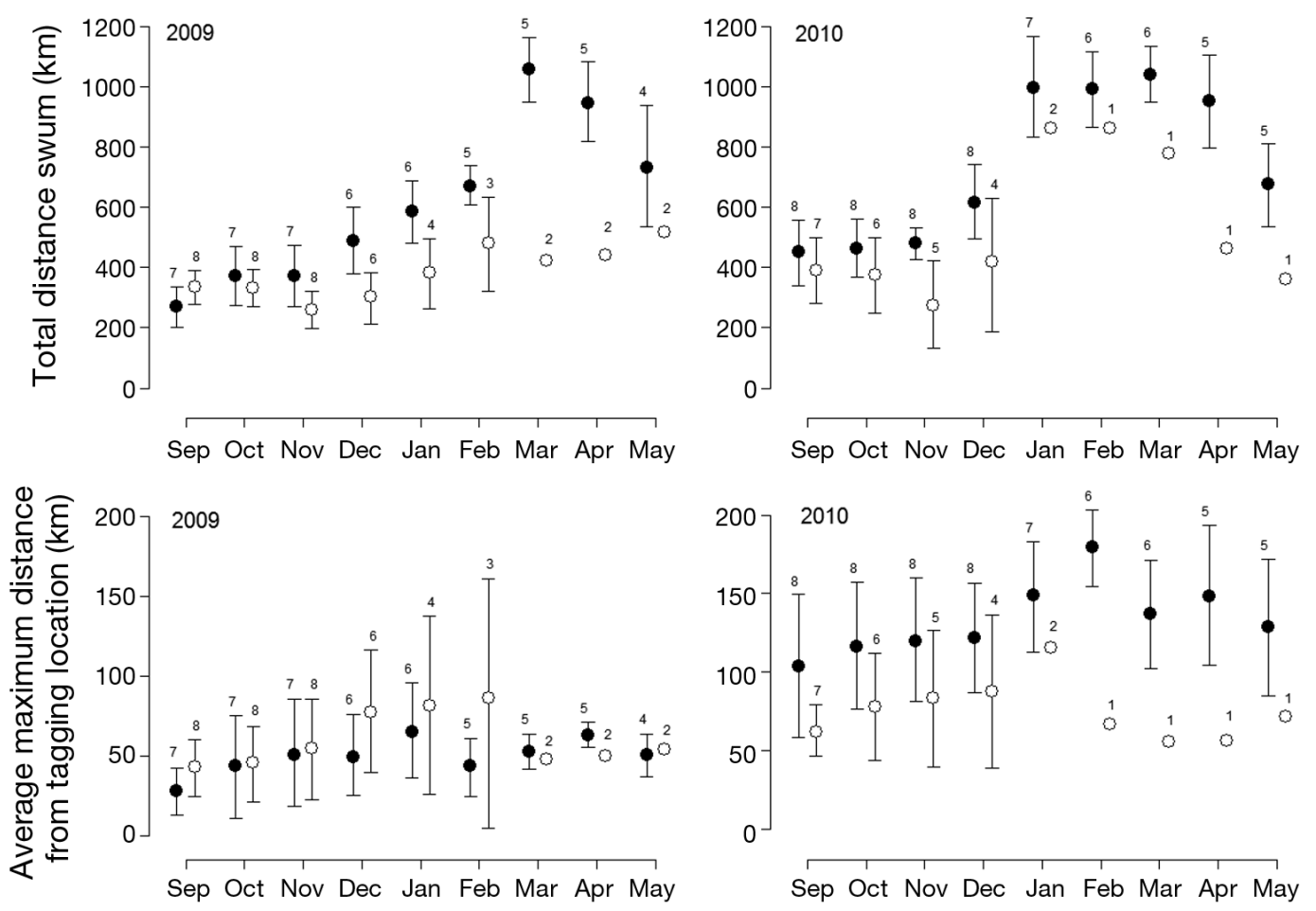

Fig. 2. Phoca vitulina. Mean and bootstrapped $95 \%$ confidence interval (CI) of the total distance swum per month and the average maximum distance from the tagging location for 30 harbour seals instrumented with CTD satellite relay data loggers (CTDSRDLs) in Svalbard, Norway in 2009 and 2010. Males are displayed with black circles and females with white circles. Only months with complete records are presented (September through May). The number of individuals in each month is displayed above each CI

more so in 2010. Trips were shorter in the immediate post-moult period $\left(\right.$ mean $_{\text {Sep2009 }}=19 \pm 17 \mathrm{~h}$ trip $^{-1}$; mean $_{\text {Sep2010 }}=18 \pm 15 \mathrm{~h} \mathrm{trip}^{-1}$ ), right after the tags were deployed, and gradually increased to a maximum around April $1\left(\right.$ mean $\left._{\mathrm{Apr} 2009}=52 \pm 56 \mathrm{~h} \mathrm{trip}^{-1}\right)$ in the first year, peaking earlier and more markedly around February 1 (mean $\left._{\mathrm{Feb} 2010} 72 \pm 63 \mathrm{~h} \mathrm{trip}^{-1}\right)$ in the second year (Fig. S1 in the Supplement at www.int-res.com/ articles/suppl/b021p167_supp.pdf). Trip duration was not influenced by sex.

\section{Home range}

Monthly HR varied greatly between individuals (Fig. 3), ranging from $4 \mathrm{~km}^{2}$ for a juvenile female in September 2010 to $1258 \mathrm{~km}^{2}$ for an adult male in February 2010. The LME explaining the greatest amount of variation in HR sizes included sea ice extent (monthly), sex and month. Age, year and the interactions between year and month did not contribute to the fit of the model (Table 3). Sea ice extent positively influenced HR size $\left(t_{1,145}=2.3, \mathrm{p}<0.05\right)$ and males had significantly larger HRs than females $\left(t_{1,28}=3.6, \mathrm{p}<0.001\right)$. There was a distinct influence of month; seals used larger HRs from December through May and smaller HRs from September to November (Fig. S2 in the Supplement, Table 3). There was no significant difference between the months within each of the 2 periods (September to November and December to May) with the exception of December and March $(z=$ $-4.06, \mathrm{p}<0.01)$. There was a moderate amount of co-

Table 2. Phoca vitulina. Different GAMM models for trip duration for 30 harbor seals equipped with CDT satellite relay data loggers (CDT-SRDLs) in Svalbard, Norway in 2009 and 2010. For each model the Akaike Information Criteria corrected for small samples $\left(\mathrm{AIC}_{\mathrm{c}}\right)$, the difference with the top-ranked model and its weight are presented. Date: starting date of a trip; year: year of tagging; age: level of maturity (adult or juvenile); ID: individual identification

\begin{tabular}{|lccc|}
\hline Model structure & $\mathrm{AIC}_{\mathrm{c}}$ & $\Delta \mathrm{AIC}_{\mathrm{c}}$ & $\begin{array}{c}\mathrm{AIC}_{\mathrm{c}} \\
\text { weight }\end{array}$ \\
\hline f(date,by=year) + (1IID) & 43185.86 & 0 & 0.764 \\
$f$ (date,by=year) + sex + age + (1IID) & 43188.24 & 2.374 & 0.233 \\
$f($ date) + sex + age + year + (1IID) & 43198.14 & 12.278 & 0.002 \\
$f($ date) + sex + (1IID) & 43199.86 & 13.999 & $<0.001$ \\
$f($ date) + sex + age + (1IID) & 43201.29 & 15.431 & $<0.001$ \\
$f$ date,by=sex) + age + year + (1IID) & 43208.74 & 22.883 & $<0.001$ \\
$f$ (date,by=age) + sex + year + (1IID) & 43211.16 & 25.301 & $<0.001$ \\
\hline
\end{tabular}



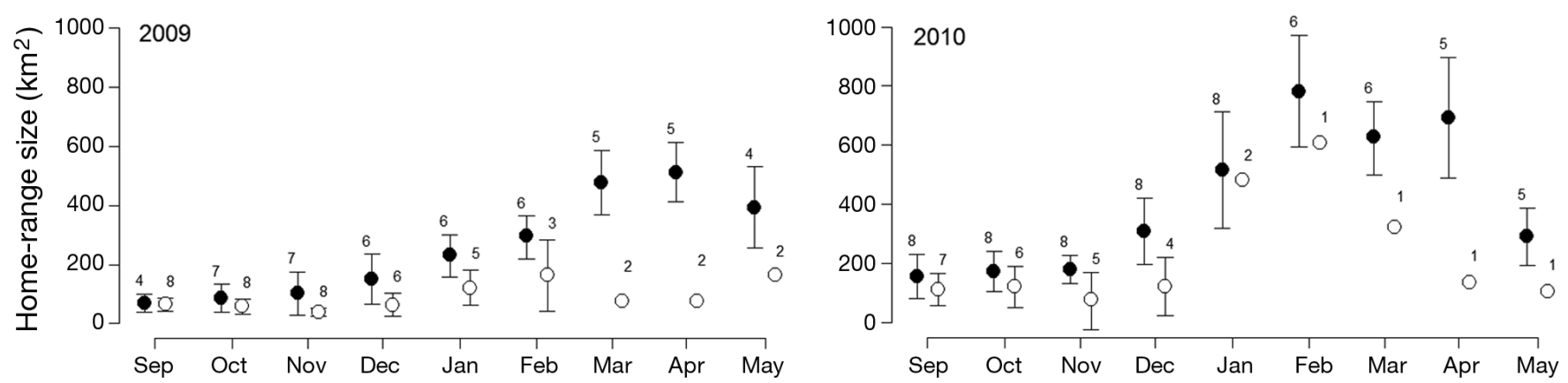

Fig. 3. Phoca vitulina. Mean (with bootstrapped $95 \%$ CI) home range size as a function of month for 30 harbour seals instrumented with CTD satellite relay data loggers (CTD-SRDLs) in Svalbard, Norway in 2009 and 2010. Males are displayed with black circles and females with white. Only animals with data for at least $25 \mathrm{~d}$ in each month are presented (September through May). The number of individuals in each month is displayed above each CI

linearity between month and sea ice extent (variance inflation factor $>3$ ), but both variables had important partial effects given that they were both included in the best fit model.

Table 3. Phoca vitulina. Parameter estimates, standard errors, degrees of freedom, $t$-values and p-values for the model that best explained the variation in home range size of harbour seals instrumented with CTD satellite relay data loggers (CTD-SRDLs) in Svalbard, Norway in 2009 and 2010. The reference level for the variables sex and month are female (F) and September respectively. Significant values are in bold

\begin{tabular}{|lrcrcc|}
\hline Parameters & Estimates & SE & df & $t$ & $\mathrm{p}$ \\
\hline Intercept & 3.815 & 0.199 & 145 & 19.149 & $<\mathbf{0 . 0 0 1}$ \\
Sex (male) & 0.872 & 0.242 & 28 & 3.601 & $<\mathbf{0 . 0 0 1}$ \\
Month (Oct) & -0.075 & 0.150 & 145 & -0.499 & 0.618 \\
Month (Nov) & -0.417 & 0.218 & 145 & -1.915 & 0.057 \\
Month (Dec) & 0.189 & 0.204 & 145 & 0.924 & 0.357 \\
Month (Jan) & 0.626 & 0.240 & 145 & 2.609 & $<\mathbf{0 . 0 1}$ \\
Month (Feb) & 0.989 & 0.247 & 145 & 4.013 & $<\mathbf{0 . 0 0 1}$ \\
Month (Mar) & 1.025 & 0.252 & 145 & 4.060 & $<\mathbf{0 . 0 0 1}$ \\
Month (Apr) & 0.959 & 0.257 & 145 & 3.733 & $<\mathbf{0 . 0 0 1}$ \\
Month (May) & 0.678 & 0.230 & 145 & 2.943 & $<\mathbf{0 . 0 1}$ \\
Sea ice extent & $<0.001$ & $<0.001$ & 145 & 2.227 & $<\mathbf{0 . 0 5}$ \\
\hline
\end{tabular}

\section{Habitat use}

Several variables influenced TSA and the most appropriate $\mathrm{CPH}$ model (based on the lowest $\mathrm{BIC}_{i}$ see Table 4) included sea ice concentration, slope, distance to the coast, sex and the interaction between distance to the coast and month. Coefficients for ice, month, sex, bathymetry, distance and distance $x$ month are presented in Table 5. TSA ranged from 1 to $94 \mathrm{~h}$. Females were generally more stationary $(\mathrm{TSA}=4.1 \pm 6 \mathrm{~h})$ than males $(\mathrm{TSA}=2.4 \pm 3.9 \mathrm{~h})$. This was confirmed by the hazard ratio associated with sex, which showed that the risk of leaving an area for a male was on average $35 \%$ higher than for a female (Table 5). TSA was also significantly influenced by sea ice concentration; animals spent twice as much time on average in nearly ice-free waters (ca. $5 \%$ ice concentration) compared to waters containing close drift ice (ca. 95\% ice concentration) (Fig. 4). $\mathrm{CPH}$ modelling suggested that there was no significant change in the risk of leaving an area between the lowest ice concentrations ( $25 \%)$ and nearly ice-free waters but that heavier ice concentrations (>55\%) were associated with an increased risk of leaving

Table 4. Phoca vitulina. Model ranking (most parsimonious model at the top in bold) based on Bayesian Information Criterion (BIC) for time spent in area (TSA) for harbour seals instrumented with CTD satellite relay data loggers (CTD-SRDLs) in Svalbard, Norway in 2009 and 2010. Log(L): log likelihood; age: level of maturity (adult or juvenile); ice: a categorical variable representing the ice concentration with 5 levels; slope: a continuous variable representing the computed slope from bathymetric values from 8 neighbour cells; bat: the bathymetry as a categorized variable $(0-100 \mathrm{~m}, 100-200 \mathrm{~m}$ or $>200 \mathrm{~m}$ depth); dist: the distance to the nearest coast as a categorized variable $(0-10 \mathrm{~km}, 10-50 \mathrm{~km},>50 \mathrm{~km})$

\begin{tabular}{|c|c|c|c|c|}
\hline Model & $\mathrm{BIC}$ & $\log (\mathrm{L})$ & $\mathrm{df}$ & $\mathrm{BIC}_{\mathrm{c}}$ weight \\
\hline Bat + Dist + Ice + Month + Sex + Slope + Dist $\times$ Month & 624887.7 & -312282 & 31 & 0.995 \\
\hline Age + Bat + Dist + Ice + Month + Sex + Slope + Dist $\times$ Month & 624898.1 & -312282 & 32 & 0.005 \\
\hline Bat + Dist + Month + Sex + Slope + Dist $\times$ Month & 624914.5 & -312317 & 27 & 0 \\
\hline Bat + Ice + Month + Sex + Slope & 624915.1 & -312369 & 17 & 0 \\
\hline Bat + Dist + Ice + Month + Sex + Slope & 624922.2 & -312362 & 19 & 0 \\
\hline Age + Bat + Dist + Month + Sex + Slope + Dist $\times$ Month & 624924.4 & -312316 & 28 & 0 \\
\hline Age + Bat + Ice + Month + Sex + Slope & 624925.5 & -312369 & 18 & 0 \\
\hline
\end{tabular}


Table 5. Phoca vitulina. Effects of ice concentration, slope, month, sex, bathymetry and distance to the nearest coast, obtained by modeling the time spent in an area (TSA) $(2.5 \times 2.5 \mathrm{~km})$ for harbour seals instrumented with CTD satellite relay data loggers (CTD-SRDLs) in Svalbard, Norway in 2009 and 2010. $\beta$ : Cox proportional hazard coefficients; $\exp (\beta)$ : hazard ratios; CI: $95 \%$ confidence intervals. Coefficients are given in relation to the ice concentration Category I, September, for females, for a bathymetry comprised between 0 and $100 \mathrm{~m}$ and for a distance to the coast between 0 and $10 \mathrm{~km}$. The number of observations $(\mathrm{N})$ in each category is also given. Significant values are in bold

\begin{tabular}{|c|c|c|c|c|c|c|}
\hline \multirow{2}{*}{ Variable } & \multirow[t]{2}{*}{$\mathrm{N}$} & \multirow[t]{2}{*}{$\beta$} & \multirow{2}{*}{$\exp (\beta)$} & \multicolumn{2}{|c|}{$\longrightarrow \mathrm{CI} \longrightarrow$} & \multirow[t]{2}{*}{$\mathrm{p}$} \\
\hline & & & & Lower & Upper & \\
\hline Ice (I) & 18047 & - & - & - & - & - \\
\hline Ice (II) & 6128 & -0.018 & 0.982 & 0.950 & 1.015 & 0.27 \\
\hline Ice (III) & 5062 & 0.054 & 1.055 & 1.018 & 1.094 & $<0.001$ \\
\hline Ice (IV) & 3609 & 0.153 & 1.165 & 1.116 & 1.216 & $<0.001$ \\
\hline Ice (V) & 481 & 0.151 & 1.163 & 1.058 & 1.279 & $<0.001$ \\
\hline Slope & 33327 & -0.042 & 0.958 & 0.949 & 0.969 & $<0.001$ \\
\hline Month (Sep) & 2740 & - & - & - & - & - \\
\hline Month (Oct) & 2839 & -0.139 & 0.871 & 0.826 & 0.918 & $<0.001$ \\
\hline Month (Nov) & 2725 & -0.265 & 0.767 & 0.726 & 0.811 & $<0.001$ \\
\hline Month (Dec) & 3274 & -0.258 & 0.772 & 0.731 & 0.816 & $<0.001$ \\
\hline Month (Jan) & 4896 & -0.155 & 0.856 & 0.807 & 0.909 & $<0.001$ \\
\hline Month (Feb) & 4845 & 0.004 & 1.004 & 0.940 & 1.072 & 0.91 \\
\hline Mon & 4705 & 0.110 & 1.116 & 1.049 & 1.189 & $<0.001$ \\
\hline Month (Apr) & 3961 & 0.248 & 1.282 & 1.204 & 1.365 & $<0.001$ \\
\hline Month (May) & 2687 & 0.065 & 1.0673 & 1.005 & 1.134 & $<0.05$ \\
\hline Month (Jun) & 655 & 0.193 & 1.213 & 1.103 & 1.333 & $<0.001$ \\
\hline Sex ( & 7999 & - & - & - & - & - \\
\hline Sex (male) & 25328 & 0.303 & 1.353 & 1.318 & 1.390 & $<0.001$ \\
\hline Bat $(0-10$ & 21437 & - & - & - & - & - \\
\hline Bat $(100-200 \mathrm{~m})$ & 8821 & 0.242 & 1.274 & 1.235 & 1.314 & $<0.001$ \\
\hline Bat $(<200 \mathrm{~m})$ & 3069 & 0.531 & 1.701 & 1.627 & 1.780 & $<0.001$ \\
\hline Dist $(0-10 \mathrm{~km})$ & 20782 & - & - & - & - & - \\
\hline Dist $(10-50 \mathrm{~km})$ & 12099 & 0.457 & 1.580 & 1.278 & 1.953 & $<0.001$ \\
\hline $\operatorname{Dist}(>50 \mathrm{~km})$ & 446 & -0.430 & 0.650 & 0.309 & 1.368 & 0.26 \\
\hline Dist $(0-10 \mathrm{~km})$ :Sep & & - & - & - & - & - \\
\hline Dist $(10-50 \mathrm{~km})$ :Oct & & -0.261 & 0.770 & 0.529 & 1.123 & 0.18 \\
\hline Dist $(10-50 \mathrm{~km}): \mathrm{Nov}$ & & -0.033 & 0.968 & 0.745 & 1.256 & 0.80 \\
\hline Dist $(10-50 \mathrm{~km}): \mathrm{Dec}$ & & -0.123 & 0.884 & 0.702 & 1.115 & 0.30 \\
\hline Dist $(10-50 \mathrm{~km}): J a n$ & & -0.345 & 0.708 & 0.569 & 0.882 & $<0.001$ \\
\hline Dist (>50 km):Jan & & 0.528 & 1.696 & 0.793 & 3.628 & 0.17 \\
\hline Dist $(10-50 \mathrm{~km}):$ Feb & & -0.454 & 0.634 & 0.509 & 0.791 & $<0.001$ \\
\hline Dist $(>50$ & & 0.761 & 2.141 & 1.007 & 4.552 & 0.05 \\
\hline Dist $(10-50 \mathrm{~km}): M a r$ & & -0.485 & 0.615 & 0.494 & 0.766 & $<0.001$ \\
\hline Dist $(>50 \mathrm{~km}):$ Ma & & 0.078 & 1.081 & 0.362 & 3.226 & 0.89 \\
\hline Dist $(10-50 \mathrm{~km}): A p r$ & & -0.625 & 0.535 & 0.429 & 0.667 & $<0.001$ \\
\hline Dist (1 & & -0.603 & 0.547 & 0.436 & 0.686 & $<0.001$ \\
\hline Dist $(10-50 \mathrm{~km}): J u n$ & & -0.239 & 0.787 & 0.594 & 1.042 & 0.09 \\
\hline
\end{tabular}

influence of distance to the coast was complex to interpret due to its interaction with month, but generally the risk of leaving an area increased with distance to the coast (increased risk of leaving by $58 \%$ for distances 10 to $50 \mathrm{~km}$ ) except in January, February, March, April and May when drift ice is more likely to be present close to shore (Fig. S3). Fig. 5 shows the predicted risk of leaving based on water depth, distance to coast, slope and sea ice for males in September in the absence of sea ice. Female patterns were similar (not shown). The variables used to produce the predictions were bound to the range of values in the original dataset to avoid extrapolation beyond the span of the model. The seals had lower risks of leaving an area that was shallow and close to the coast; deep water is clearly avoided by most seals (Fig. 5).

\section{DISCUSSION}

This study is one of few that have explored harbour seal behaviour at the edge of their distributional range in seasonally ice-covered waters (Gjertz et al. 2001, Lesage et al. 2004, Bajzak et al. 2013). It is by far the most extensive in terms of number of animals instrumented (30 ind. over $2 \mathrm{yr})$ and average durations of data streams (200 d), which spanned from the immediate post-moulting period to late spring of the following year,

(by up to $16 \%$ compared to nearly ice-free waters; Table 5, Fig. S3 in the Supplement). Bathymetry was an influential parameter, with the risk of leaving increasing with depth $(71 \%$ higher for water depths of $>200 \mathrm{~m}$ compared to water depths between 0 and $100 \mathrm{~m})$. The seals also appeared to prefer particular benthic habitats; CPH showed a decreased risk of leaving areas associated with steeper slopes.

Seasonal differences in the temporal and spatial use of available habitat were also displayed by the seals. For example, months from October through to January were associated with a lower risk of leaving relative to September, while the tendency to leave an area increased from February through June. The taking them through most of the ice-covered period in the Svalbard region. Previous studies on harbour seals movement patterns indicate that this species is relatively sedentary throughout the year, although seasonal shifts between favoured sites is common and in some areas the seals make offshore trips in the vicinity of the main haul-out sites to distances between 20 and $30 \mathrm{~km}$ (Thompson \& Miller 1990, Thompson et al. 1991, Thompson et al. 1998b, Vincent et al. 2010, Sharples et al. 2012). However, longdistance movements have also been recorded in some areas, linked mainly to seasonal migrations to avoid ice or dispersal by immature animals (Lesage et al. 2004, Peterson et al. 2012, Sharples et al. 2012, 


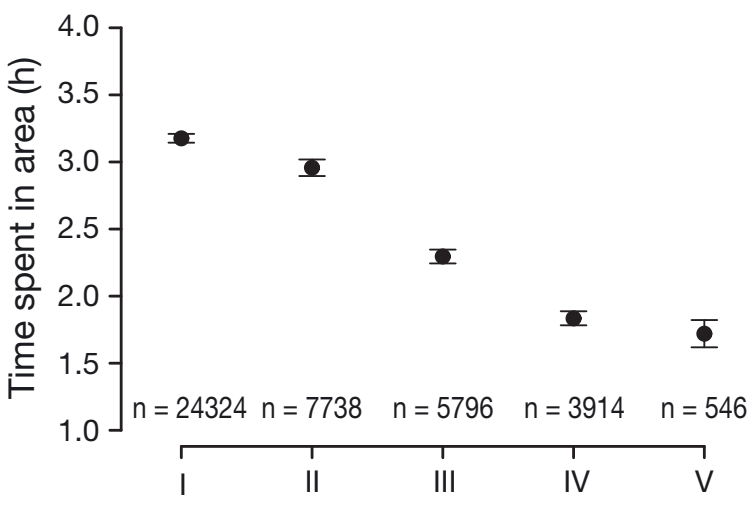

Fig. 4. Phoca vitulina. Mean $\pm \mathrm{SE}$ of time spent in an area $(2.5 \times 2.5 \mathrm{~km})$, by 30 adult or juvenile harbour seals instrumented with CTD satellite relay data loggers (CTD-SRDLs) in Svalbard, Norway in 2009 and 2010 as a function of sea ice concentration for 2009 and 2010. The ice concentration categories correspond to I = open water, II = very open drift ice, $\mathrm{III}=$ open drift ice, $\mathrm{IV}=$ close drift ice, $\mathrm{V}=$ very close drift ice. The number of $2.5 \times 2.5 \mathrm{~km}$ cells considered in each category is indicated

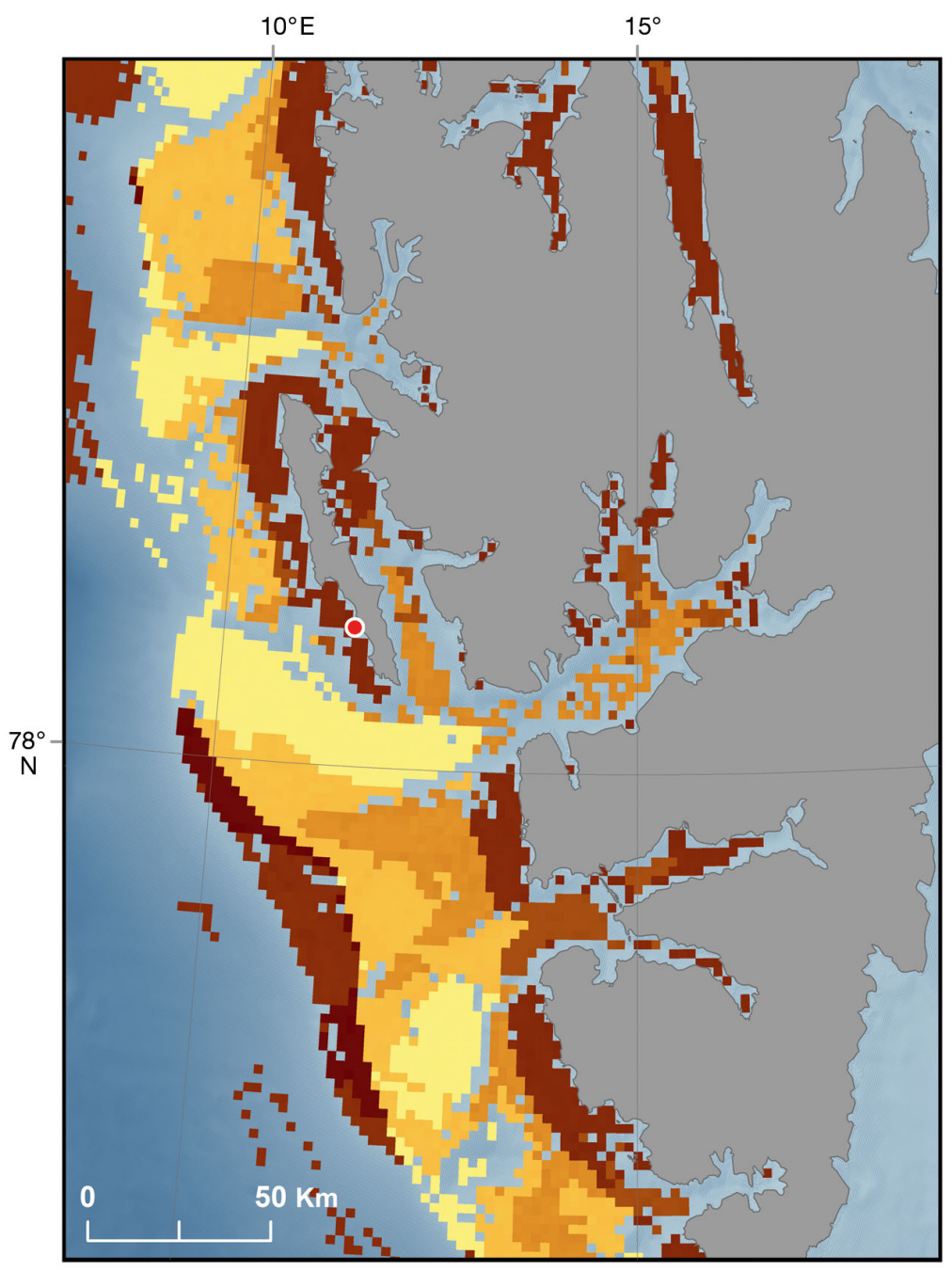

Bajzak et al. 2013, Womble \& Gende 2013). In the present study, all of the animals stayed within $100 \mathrm{~km}$ of the coast of Spitsbergen throughout the study period, though some few individuals dispersed away from the tagging location at $\mathrm{PKF}$, travelling up to $\sim 230 \mathrm{~km}$. PKF is the main haul-out area and the only recorded pupping site on Svalbard (Lydersen \& Kovacs 2010). Gjertz et al. (2001) suggested that harbour seals that disperse to other areas of Svalbard likely return to PKF for pupping, mating and possibly moulting. Identified terrestrial haul-out sites are certainly not limited to $\mathrm{PKF}$; animals haul out along much of the west coast of Spitsbergen (Hamilton et al. 2014), demonstrating that at least some individuals are not resident around PKF throughout the year. The large individual variations observed in movement metrics in this study suggest the existence of individual strategies, with part of the population staying close to PKF while other individuals disperse much more broadly, though members of this population remain tied to the west coast of Spitsbergen. The reason for their residency in this area is likely a combination of several features including water depth and water temperature as well as biotic factors such as predation risk levels and availability of suitable prey.

Bathymetry was an influential parameter in the habitat selection model (Table 5) in this study; individuals showed a marked preference for water depths shallower than $100 \mathrm{~m}$. The seals also clearly avoided deep channels located in front of fjord mouths and did not go into deep waters off the shelf either (Figs. 1 \& 5). These results are consistent with previous observations from Svalbard (Gjertz et al. 2001, Krafft et al. 2002) where all dives were shallower than $250 \mathrm{~m}$

Fig. 5. Phoca vitulina. A composite grid showing predicted habitat use intensities for harbour seals instrumented with CTD satellite relay data loggers (CTD-SRDLs) in Svalbard, Norway in 2009 and 2010, displaying the estimated risk of leaving a $2.5 \times 2.5 \mathrm{~km}$ area. Predictions were based on bathymetry, slope and ice concentration extracted at the centre of each grid cell for males in September. The variables used to produce the predictions were bound to the range of values in the data to avoid extrapolating beyond the span of the model. Warmer colours indicate lower risks of leaving an area (i.e. preferred areas). Red dot indicates tagging location 
and half of the diving performed was shallower than $40 \mathrm{~m}$. Edges along steep slopes close to the coast were favoured by the seals in this study, with a decreased risk of leaving an area of $5 \%$ for each additional degree of steepness (Table 5). However, this finding might be heavily influenced by a few individuals that spent large amounts of time foraging along the edge of the continental slope in slightly deeper waters (Fig. 5).

Areas within $50 \mathrm{~km}$ of the coast were more attractive to the seals regardless of the time of the year. Shallow coastal waters and Arctic shelves are generally areas of high productivity where nutrients are easily mixed in the water column (Reigstad et al. 2011). This is particularly true for the west coast of Spitsbergen where cold, relatively fresh Arctic water meets and mixes at the Polar Front with warmer, more saline Atlantic water carried northward by the West Spitsbergen Current (Boyd \& D'Asaro 1994, Eriksen et al. 2012). This mixing is enhanced by steep bathymetric features like the continental shelf break, which is located $35 \mathrm{~km}$ west of PKF, and the strong surface winds that occur on the west coast of Spitsbergen, rendering this area very productive (Cottier et al. 2007, Ingvaldsen \& Loeng 2009). Indeed, primary productivity derived from model simulations show that the highest values are found tied with regions dominated by inflows of Atlantic waters in the western and southeastern parts of Spitsbergen. However, the latter areas in the southeast are found at large distances from the coast (Reigstad et al. 2011). This explain why none of the harbour seals in this study went to the east coast; this resource-rich area is likely too far from the coast to be profitable (Fig. 1), despite the absence of sea ice during the summer and bathymetric and slope conditions similar to the areas in the west that they do use.

Polar bear Ursus maritimus densities on the west coast are lower than in the north or east of Svalbard, which likely reinforces the harbour seals' preference for the west coast of Spitsbergen (Mauritzen et al. 2001, Mauritzen et al. 2002, Freitas et al. 2012). Interestingly, seals seem to avoid entering nearby deep fjord systems on the west coast even though these areas have features identified as favourable in our model. This might be linked to the fact that the fjords in this region are often dominated by Arctic water, with warm Atlantic water entering the fjord systems only under unusual wind and current conditions (Berge et al. 2005). Additionally, ringed seals Pusa hispidawhich overlap in terms of diet with harbour seals - occupy the fjords (Lydersen 1998, Freitas et al. 2008c), and competitive exclusion might occur.
Whether all of the animals in this study returned to PKF for the breeding season following their tracking period is uncertain because many of the data records terminated too early, but the few animals (mainly males) still transmitting data in June were all close to the island. Studies of harbour seals in Alaska have shown that although some individuals undertake extensive migratory movements (up to $900 \mathrm{~km}$ away from pupping sites), there is a substantial degree of site fidelity, with $93 \%$ of the females returning to their original tagging site for the following breeding season (Womble \& Gende 2013).

Svalbard harbour seals increased their daily travel distance, trip duration and HR size towards the winter months. Changes in distribution in other harbour seal populations have been linked to changes in prey availability (Thompson et al. 1991, 1996), which might also be the case here. Gadoid species (the cod family) were the most abundant prey consumed by harbour seals on Svalbard in the study period (Colominas 2012) with Atlantic cod Gadus morhua and polar cod Boreogadus saida being particularly important in the diet. The polar cod is a dominant fish species on Arctic shelves and is tightly linked to Arctic water masses, while Atlantic cod is associated with Atlantic water in cold, north temperate areas (Renaud et al. 2012, Hop \& Gjøsæter 2013). The west coast of Spitsbergen is strongly influenced by both of these water masses and their relative dominance changes both seasonally and inter-annually in this region (Willis et al. 2008). In such an environment, seasonal dietary changes would be expected and have previously been suggested for harbour seals in the Svalbard population (Gjertz et al. 2001, Andersen et al. 2004). In recent years, increased influxes of warm Atlantic water have taken place on the west coast of Svalbard and a northward expansion of Atlantic cod has been observed (Renaud et al. 2012, Hop \& Gjøsæter 2013).

Other environmental features in Svalbard that likely limit harbour seal distribution are strongly seasonal. Hamilton et al. (2014) have shown that harbour seals from Svalbard spend less time hauled out (and consequently more time in the water) during the winter compared to summer and suggested that it could be a strategy to avoid thermal stress when hauling out on ice in winter when air temperatures can drop below $-30^{\circ} \mathrm{C}$. However, the potential thermal challenges imposed by low winter temperatures are unlikely to be the only reason for the increased aquatic behaviour, since increased time spent in the water and increasing distances travelled per day occurred concomitantly. On the west coast of Spitsbergen the 
winter months are usually associated with the arrival of drifting pack ice along the outer shores and also some land-fast sea ice in the fjords (Vinje 2009). A strong coastal Arctic current brings drift ice from around the southern tip of the Spitsbergen northward (Vinje 2009) along the west coast; the distribution of this drifting ice is then determined by wind direction and the action of other currents. High sea ice concentrations and land-fast sea ice are limiting factors for harbour seals because they cannot maintain breathing holes like ringed seals do and rapidly changing ice conditions might force the seals to travel more to avoid being caught in the ice (Mansfield 1967, Lesage et al. 2004, Bajzak et al. 2013). This general pattern is supported by the $\mathrm{CPH}$ habitat use model in this study that shows that high ice concentrations increased the risk of leaving an area. There was also a positive relationship between sea ice extent and HR size. However, the seals did use moderately ice-covered areas and they travelled through ice concentrations up to $55 \%$. Sea ice extent was more important in the second year of this study, when ice cover was heaviest and HR sizes were also larger during the second winter.

Ice cover might also have some positive aspects for harbour seals. In the St Lawrence River Estuary in Canada, the presence of ice cover is known to concentrate food resources in areas of open water and along ice edges, increasing the ease of access to prey for this seal species (Lesage et al. 2004). This could also be the case in Svalbard, at least during periods when there is sufficient light to trigger phytoplankton blooms (Engelsen et al. 2002, Hop \& Gjøsæter 2013). It is however difficult to test this hypothesis given the low resolution of ice maps for the region, which do not permit fine-scale spatial analyses for precisely where the seals were within ice-covered areas.

Age, size and sex have also been shown to influence movement patterns of harbour seals (Thompson et al. 1998b, Peterson et al. 2012). Thompson et al. (1998b) reported that sex and body size were correlated with trip duration in harbour seals in Moray Firth (Scotland) and that males had larger foraging ranges than females. The present study is in agreement with these observations; males generally had larger HRs than females, travelled greater distances per day and had a higher risk of leaving areas, suggesting that they were generally less sedentary. Possible reasons for this gender difference in at-sea movements are different reproduction costs for the 2 sexes and different levels of intra-specific competition. No age effects were found for any of the movement metrics, which suggests that body size differences were not responsible for the observed differences in at-sea movements, leaving a more intrinsic sex difference as the likely explanation. Males and females might have somewhat different diets for parts of the year, but no sex-related dietary information exists for Svalbard's harbour seals to explore this suggestion.

Climate change has already had major influences on air and water temperatures in Svalbard and dramatically changed the sea-ice cover in this region (Pavlov et al. 2013, Nordli et al. 2014). Forward-looking climate scenarios predict that the Barents Sea ecosystem will continue to experience rapid unidirectional change that will include higher sea surface temperature, increased frequency of strong winds, decreases in sea-ice cover and extension of the icefree period (see Vinje 2009 and Kovacs et al. 2011 for reviews). This physical environmental change is expected to cause a shift in species distributions and abundance and to affect all trophic levels within the Arctic ecosystem (e.g. Gilg et al. 2012). Already, exceptionally warm years have occurred and some boreal fish species have been recorded at the northernmost edges of their distribution range (Wienerroither et al. 2011). With the predicted increase of Atlantic water inflow through the Fram Strait this situation is likely to become more common in the future, affecting the type and distribution of prey for the harbour seals in this region. The recent increases in water temperature and reduction in sea ice seen in Svalbard are predicted to intensify in the future, which are likely to make conditions in the archipelago more favourable for harbour seals by increasing the available habitat.

In summary, we present the first year-round observations of at-sea movements of juvenile and adult harbour seals from the world's northernmost population, residing in the high-Arctic archipelago of Svalbard. Tracking data provides a solid baseline for understanding how individuals from this population use their environment currently and provide a basis for predicting how they might react to environmental change in the future (New et al. 2014). It revealed that animals show a strong preference for the west coast of Spitsbergen through all seasons. None of the animals travelled to the east side of Spitsbergen, suggesting that they do not find sufficiently favourable conditions there, despite the absence of sea ice during part of the year and the presence of available terrestrial haul-out platforms. The influx of warm saline Atlantic water that occurs close to the coast on the west side of the islands is likely essential for 
maintaining a high productivity area close to the coast via mixing of water masses and shelf upwelling, along with tolerable amounts of sea ice in the winter. The recent increases in water temperature and reduction in sea ice seen in Svalbard are predicted to intensify in the future, thus making conditions in the archipelago more favourable for harbour seals.

Acknowledgements. We thank Lisa LeClerc, Benjamin Merkel, Morten Tryland and Bjørn Waalberg for their assistance in the field.

\section{LITERATURE CITED}

Andersen SM, Lydersen C, Grahl-Nielsen O, Kovacs KM (2004) Autumn diet of harbour seals (Phoca vitulina) at Prins Karls Forland, Svalbard, assessed via scat and fatty-acid analyses. Can J Zool 82:1230-1245

> Andersen LW, Lydersen C, Frie AK, Rosing-Asvid A, Hauksson E, Kovacs KM (2011) A population on the edge: genetic diversity and population structure of the world's northernmost harbour seals (Phoca vitulina). Biol J Linn Soc 102:420-439

> Bajzak C, Bernhardt W, Mosnier M, Hammill M, Stirling I (2013) Habitat use by harbour seals (Phoca vitulina) in a seasonally ice-covered region, the western Hudson Bay. Polar Biol 36:477-491

Berge J, Johnsen G, Nilsen F, Gulliksen B, Slagstad D (2005) Ocean temperature oscillations enable reappearance of blue mussels Mytilus edulis in Svalbard after a 1000 year absence. Mar Ecol Prog Ser 303:167-175

Bigg MA (1969) The harbour seal in British Columbia. Bull Fish Res Board Can 172:1-33

Bjørge A, Thompson D, Hammond P, Fedak M and others (1995) Habitat use and diving behaviour of harbour seals in a coastal archipelago in Norway. In: Blix AS, Walløe L, Ulltang $\varnothing$ (eds) Whales, seals, fish and man. Proc Int Symp Biol Mar Mamm NE Atl, Tromsø, Norway, 29 Nov to 1 Dec 1994. Elsevier, Amsterdam, p 211-223

Blundell GM, Womble JN, Pendleton GW, Karpovich SA, Gende SM, Herreman JK (2011) Use of glacial and terrestrial habitats by harbor seals in Glacier Bay, Alaska: costs and benefits. Mar Ecol Prog Ser 429:277-290

Boehme L, Lovell P, Biuw M, Roquet F and others (2009) Animal-bourne CTD-Satellite relay data loggers for realtime oceanographic data collection. Ocean Sci 5:685-695

Boyd TJ, D'Asaro EA (1994) Cooling of the west Spitsbergen current: wintertime observations west of Svalbard. J Geophys Res 99(C11):22597-22618

Burnham KP, Anderson DR (eds) (2002) Model selection and multimodel inference: a practical information-theoretic approach. Springer, New York, NY

Calenge $C$ (2011) Home range estimation in R: the adehabitat HR package. http://cran.at.r-project.org/web/ packages/adehabitatHR/vignettes/adehabitatHR.pdf

Chavez-Rosales S, Gardner SC (1999) Recent harbour seal (Phoca vitulina richardsi) pup sightings in Magdalena Bay, Baja California Sur, Mexico. Aquat Mamm 25: 169-171

Collett D (ed) (2003) Modelling survival data in medical research, 2nd edn. Chapman \& Hall, CRC, Boca Raton, FL
Colominas R (2012) Harbour seal diet in a changing Arctic (Svalbard, Norway). MSc thesis, University of Bergen

Cottier FR, Nilsen F, Inall ME, Gerland S, Tverberg V, Svendsen H (2007) Wintertime warming of an Arctic shelf in response to large-scale atmospheric circulation. Geophys Res Lett 34:L10607, doi:10.1029/2007GL029948

Cox DR (1972) Regression models and life tables (with discussion). J R Stat Soc B 34:187-120

Engelsen O, Hegseth EN, Hoop H, Hansen E, Falk-Petersen S (2002) Spatial variability of chlorophyll-a in the Marginal Ice Zone of the Barents Sea with relations to sea ice and oceanographic conditions. J Mar Syst 35:79-97

Eriksen E, Ingvaldsen R, Stiansen JE, Johansen GO (2012) Thermal habitat for 0-group fish in the Barents Sea; how climate variability impacts their density, length, and geographic distribution. ICES J Mar Sci 69:870-879

Freitas C (2013) Package 'Argosfilter'. http://cran.at.r-project. org/web/packages/argosfilter/argosfilter.pdf

Freitas C, Kovacs KM, Ims RA, Lydersen C (2008a) Predicting habitat use by ringed seals (Phoca hispida) in a warming Arctic. Ecol Modell 217:19-32

Freitas C, Kovacs KM, Lydersen C, Ims RA (2008b) A novel method for quantifying habitat selection and predicting space use. J Appl Ecol 45:1213-1220

> Freitas C, Lydersen C, Fedak MA, Kovacs KM (2008c) A simple new algorithm to filter marine mammal Argos locations. Mar Mamm Sci 24:315-325

> Freitas C, Kovacs KM, Andersen M, Aars J and others (2012) Importance of fast ice and glacier fronts for female polar bears and their cubs during spring in Svalbard, Norway. Mar Ecol Prog Ser 447:289-304

Frost KJ, Lowry LF, Ver Hoef JM (1999) Monitoring the trend of harbor seals in Prince William Sound, Alaska, after the Exxon Valdez oil spill. Mar Mamm Sci 15:494-506

> Gilg O, Kovacs KM, Aars J, Fort J and others (2012) Climate change and the ecology and evolution of Arctic vertebrates. Ann N Y Acad Sci 1249:166-190

Gjertz I, Børset A (1992) Pupping in the most northerly harbour seals (Phoca vitulina). Mar Mamm Sci 8:103-109

> Gjertz I, Lydersen C, Wiig Ø (2001) Distribution and diving of harbour seals (Phoca vitulina) in Svalbard. Polar Biol 24:209-214

Hamilton CD, Lydersen C, Ims RA, Kovacs KM (2014) Haulout behaviour of the world's northermost population of harbour seals (Phoca vitulina) throughout the year. PLoS ONE 9:e86055

Hanson N, Thompson D, Duck C, Moss S, Lonergan M (2013) Pup mortality in a rapidely declining harbour seal (Phoca vitulina) population. PLoS ONE 8:e80727

Hassani S, Dupuis L, Elder JF, Caillot E and others (2010) A note on harbour seal (Phoca vitulina) distribution and abundance in France and Belgium. NAMMCO Sci Publ 8:107-116

Hauksson E (1992) Counting of common seals (Phoca vitulina L.) and grey seals (Halichoerus grypus Fabr.) in 1980-1990, and the state of the seal population at the coast of Iceland. Hafrannsoknir 43:5-22 (in Icelandic with a summary in English)

Hijmans RJ, van Etten J, Mattiuzzi M, Summer M and others (2014) Raster: geographic data analysis and modeling. http://cran.at.r-project.org/web/packages/raster/raster.pdf

Hop H, Gjøsæter H (2013) Polar cod (Boreogadus saida) and capelin (Mallotus villosus) as key species in marine food webs of the Arctic and the Barents Sea. Mar Biol Res 9: 878-894 
Horne JS, Garton EO, Krone SM, Lewis JS (2007) Analysing animal movements using brownian bridges. Ecology 88: 2354-2363

Hothorn T, Bretz F, Westfall P, Heiberger R, Schuetzenmeister A (2014) multcomp: simultaneous inference in general parametric models. http://cran.r-project.org/web/ packages/multcomp/index.html

Ingvaldsen R, Loeng $H$ (2009) Physical oceanography. In: Sakshaug E, Johnsen G, Kovacs K (eds) Ecosystem Barents Sea. Tapir Academic Press, Trondheim, p 33-64

Jakobsson M, Mayer LA, Coakley B, Dowdeswell JA and others (2012) The international bathymetric chart of the Arctic Ocean (IBCAO) v. 3.0. Geophys Res Lett 39: L12609, doi:10.1029/2012GL052219

> Jeffries S, Huber H, Calambokidis J, Laake J (2003) Trends and status of harbor seals in Washington State: 19781999. J Wildl Manag 67:207-218

Johnson DS (2013) Crawl: fit continuous-time correlated random walk models to animal movement data. http: //cran.r-project.org/web/packages/crawl/index.html

Kovacs KM, Lydersen C, Overland JE, Moore SE (2011) Impacts of changing sea-ice conditions on Arctic marine mammals. Mar Biodivers 41:181-194

Krafft BA, Lydersen C, Gjertz I, Kovacs KM (2002) Diving behaviour of sub-adult habour seals (Phoca vitulina) at Prins Karls Forland, Svalbard. Polar Biol 25:230-234

> Lesage V, Hammill MO, Kovacs KM (2004) Long-distance movements of harbour seals (Phoca vitulina) from a seasonally ice-covered area, the St. Lawrence River estuary, Canada. Can J Zool 82:1070-1081

> Lonergan M, Duck CD, Thompson D, Mackey BL, Cunningham L, Boyd IL (2007) Using sparse survey data to investigate the declining abundance of British harbour seals. J Zool 271:261-269

> Lonergan M, Hall A, Thompson H, Thompson PM, Pomeroy P, Harwood J (2010) Comparison of the 1988 and 2002 phocine distemper epizootics in British harbour seal Phoca vitulina populations. Dis Aquat Org 88:183-188

Lonergan M, Duck C, Moss S, Morris C, Thompson D (2013) Rescaling of aerial survey data with information from small numbers of telemetry tags to estimate the size of a declining harbour seal population. Aquat Conserv 23: 135-144

Lucas ZN, Natanson LJ (2010) Two shark species involved in predation on seals at Sable Island, Nova Scotia, Canada. Proc Nova Scotia Inst Sci 45:64-88

Lucas ZN, Stobo WT (2000) Shark-inflicted mortality on a population of harbour seals (Phoca vitulina) at Sable Island, Nova Scotia. J Zool 252:405-414

Lydersen C (1998) Status and biology of ringed seals (Phoca hispida) in Svalbard. NAMMCO Sci Publ 1:46-62

Lydersen C, Kovacs KM (2005) Growth and population parameters of the world's northernmost harbour seals Phoca vitulina residing in Svalbard, Norway. Polar Biol 28:156-163

Lydersen C, Kovacs KM (2010) Status and biology of harbour seals (Phoca vitulina) in Svalbard. NAMMCO Sci Publ 8:47-60

Mansfield AW (1967) Distribution of the harbor seal, Phoca vitulina Linnaeus, in Canadian Arctic waters. J Mamm 48:249-257

Matthiopoulos J, Cordes L, Mackey B, Thompson D and others (2014) State-space modelling reveals proximate causes of harbour seal population declines. Oecologia 174:151-162
Mauritzen M, Derocher AE, Wiig Ø (2001) Space-use strategies of female polar bears in a dynamic sea ice habitat. Can J Zool 79:1704-1713

- Mauritzen M, Derocher AE, Wiig $\varnothing$, Belikov SE, Boltunov AN, Hansen E, Garner GW (2002) Using satellite telemetry to define spatial population structure in polar bears in Norwegian and western Russian Arctic. J Appl Ecol 39:79-90

Merkel B, Lydersen C, Yoccoz NG, Kovacs KM (2013) The world's northernmost harbour seals population-how many are they? PLoS ONE 8:e67576

> New LF, Clark JS, Costa DP, Fleishman E and others (2014) Using short-term measures of behaviour to estimate long-term fitness of southern elephant seals. Mar Ecol Prog Ser 496:99-108

Nilssen KT, Skavberg NE, Poltermann M, Haug T, Härkönen T, Henriksen G (2010) Status of harbour seals (Phoca vitulina) in mainland Norway. NAMMCO Sci Publ 8: 61-69

> Nordli Ø, Przybylak R, Ogilvie AEJ, Isaksen K (2014) Longterm temperature trends and variability on Spitsbergen: the extended Svalbard Airport temperature series, 18982012. Polar Res 33:21349

Olsen MT, Andersen SM, Teilmann J, Dietz R, Endren SMC, Linnet A, Härkönen T (2010) Status of harbour seals (Phoca vitulina) in the southern Scandinavia. NAMMCO Sci Publ 8:77-94

> Patterson TA, McConnell BJ, Fedak MA, Bravington MV, Hindell MA (2010) Using GPS data to evaluate the accuracy of state-space methods for correction of Argos satellite telemetry errors. Ecology 91:273-285

Pavlov AK, Tverberg V, Ivanov BV, Nilsen F, Falk-Petersen S, Granskog MA (2013) Warming of Atlantic water in two west Spitsbergen fjords over the last century (19122009). Polar Res 32:11206

Peterson SH, Lance MM, Jeffries SJ, Acevedo-Gutierrez A (2012) Long distance movements and disjunct spatial use of harbor seals (Phoca vitulina) in the inland waters of the Pacific northwest. PLoS ONE 7:e39046

Pinheiro J, Bates D, DebRoy S, Sarkar D (2014) nlme: Linear and nonlinear mixed effects models. http://cran.us.rproject.org/web/packages/nlme/nlme.pdf

R Development Core Team (2012) R: a language and environment for statistical computing. R Foundation for Statistical Computing, Vienna

> Reder S, Lydersen C, Arnold W, Kovacs KM (2003) Haulout behaviour of High Artcic harbour seals (Phoca vitulina vitulina) in Svalbard, Norway. Polar Biol 27:6-16

Reigstad M, Carroll J, Slagstad D, Ellingsen I, Wassmann P (2011) Intra-regional comparison of productivity, carbon flux and ecosystem composition within the northern Barents Sea. Prog Oceanogr 90:33-46

Reijnders PJH, Brasseur SMJM, Tougaard S, Siebert U, Borchardt T, Stede M (2010) Population development and status of harbour seals (Phoca vitulina) in the Wadden Sea. NAMMCO Sci Publ 8:95-105

Renaud PE, Berge J, Varpe Ø, Lønne OJ, Nahrgang J, Ottesen C, Hallanger I (2012) Is the poleward expansion by Atlantic cod and haddock threatening native polar cod, Boreogadus saida? Polar Biol 35:401-412

Rosing-Asvid A (2010) Catch history and status of the harbour seal (Phoca vitulina) in Greenland. NAMMCO Sci Publ 8:161-174

Sharples RJ, Moss SE, Patterson TA, Hammond PS (2012) Spatial variation in foraging behaviour of a marine top 
predator (Phoca vitulina) determined by a large-scale satellite tagging program. PLoS ONE 7:e37216

Small RJ, Boveng PL, Byrd GV, Withrow DE (2008) Harbor seal population decline in the Aleutian Archipelago. Mar Mamm Sci 24:845-863

Sumner MD, Luque S (2013) Spatial analysis of animal track data in R: the trip package. http://cran.r-project.org/web/ packages/trip/trip.pdf

Therneau TM (2012) A package for survival analysis in S. $\mathrm{R}$ package v. 2.36-14. http://cran.r-project.org/web/ packages/survival/survival.pdf

Thompson D, Härkönen T (2008) Phoca vitulina IUCN Red List of Threatened Species v.20132

Thompson PM, Miller D (1990) Summer foraging activity and movements of radio-tagged common seals (Phoca vitulina L.) in the Moray Firth, Scotland. J Appl Ecol 27: 492-501

Thompson PM, Fedak MA, McConnell BJ, Nicholas KS (1989) Seasonal and sex related variation in the activity patterns of common seals (Phoca vitulina). J Appl Ecol 26:521-535

Thompson PM, Pierce GJ, Hislop JRG, Miller D, Diack JSW (1991) Winter foraging by common seals (Phoca vitulina) in relation to food availability in the Inner Moray Firth, N. E. Scotland. J Anim Ecol 60:283-294

Thompson PM, McConnell BJ, Tollit DJ, MacKay A, Hunter C, Racey PA (1996) Comparative distribution, movements and diet of harbour and grey seals from the Morey Firth, N. E. Scotland. J Appl Ecol 33:1572-1584

Thompson D, Duck CD, McConnell BJ, Garrett J (1998a) Foraging behaviour and diet of lactating female southern sea lions (Otaria flavescens) in the Falkland Islands. J Zool (Lond) 246:135-146

Thompson PM, Mackay A, Tollit DJ, Enderby S, Hammond PS (1998b) The influence of body size and sex on the characteristics of harbour seal foraging trips. Can J Zool

Editorial responsibility: Graeme Hays,

Swansea, UK
76:1044-1053

> Thompson D, Lonergan M, Duck C (2005) Population dynamics of harbour seals Phoca vitulina in England: monitoring growth and catastrophic declines. J Appl Ecol 42: 638-648

Trites AW, Deecke VB, Gregr EJ, Ford JKB, Olesiuk PF (2007) Killer whales, whales, and sequential megafaunal collapse in the North Pacific: a comparative analysis of the dynamics of marine mammals in Alaska and British Columbia following commercial whaling. Mar Mamm Sci 23:751-765

Vincent C, McConnell BJ, Delayat S, Elder JF, Gautier G, Ridoux V (2010) Winter habitat use by harbour seals (Phoca vitulina) fitted with Fastloc GPS/GSM tags in two tidal bays in France. NAMMCO Sci Publ 8:285-302

Vinje T (2009) Sea-ice. In: Sakshaug E, Johnsen G, Kovacs K (eds) Ecosystem Barents Sea. Tapir Academic Press, Trondheim, p 65-82

Wienerroither R, Johannesen E, Dolgov A, Byrkjedal I and others (2011) Atlas of the Barents Sea fishes. IMR/PINRO Joint Report Series 1-2011

Willis KJ, Cottier FR, Kwasnieswski S (2008) Impact of warm water advection on the winter zooplankton community in an Arctic fjord. Polar Biol 31:475-481

Womble JN, Gende SM (2013) Post-breeding season migrations of a top predator, the harbor seal (Phoca vitulina richardii), from a marine protected area in Alaska. PLoS ONE 8:e55386

Womble JN, Pendleton GW, Mathews EA, Blundell GM, Bool NM, Gende SM (2010) Harbor seal (Phoca vitulina richardii) decline continues in the rapidly changing landscape of Glacier Bay National Park, Alaska 1992-2008. Mar Mamm Sci 26:686-697

Worton BJ (1989) Kernel methods for estimating the utilization distribution in home-range studies. Ecology 70 : 164-168

Submitted: March 17, 2014; Accepted: June 3, 2014

Proofs received from author(s): August 6, 2014 